\title{
Taxonomy of Bacillus circulans Jordan 1890: Base Composition and Reassociation of Deoxyribonucleic Acid
}

\author{
L. K. NAKAMURA* AND J. SWEZEY \\ Northern Regional Research Center, Agricultural Research Service, United States Department of \\ Agriculture, Peoria, Illinois 61604
}

The guanine-plus-cytosine $(\mathrm{G}+\mathrm{C})$ contents of 123 strains previously identified as Bacillus circulans Jordan 1890 were determined. Of the strains examined, only $18 \mathrm{had} \mathrm{G}+\mathrm{C}$ contents of 37 to $41 \mathrm{~mol} \%$, a range that included the $\mathrm{G}+\mathrm{C}$ content (38.1 mol\%) of the type strain. A major portion of the strain ( 93 strains) had $\mathrm{G}+\mathrm{C}$ contents in the range from 46 to $55 \mathrm{~mol} \%$. For seven strains the $\mathrm{G}+\mathrm{C}$ contents ranged from 42 to $45 \mathrm{~mol} \%$, and for another small group of five strains the $\mathrm{G}+\mathrm{C}$ contents ranged from 56 to $61 \mathrm{~mol} \%$. Deoxyribonucleic acid reassociation studies revealed that 10 of the 18 strains with $\mathrm{G}+\mathrm{C}$ contents of 37 to $41 \mathrm{~mol} \%$ were closedly related genetically to each other and to the type strain. This genetically related group was phenotypically quite homogeneous. Our results strongly suggested that most of the strains were misclassified as $B$. circulans. Consequently, the phenotypic heterogeneity of the species $B$. circulans Jordan 1890 was not due to inherent variability of genetically related strains, but to variability introduced by inclusion of genetically unrelated organisms.

In 1890 , Jordan described a new species and named it Bacillus circulans because the interior of its colonies, when viewed under low magnification, flowed in a circular pattern (11). Later, in 1916 , Ford isolated a strain that he considered to be the same as the strain of Jordan because its colonies also displayed interior circular movement (4). However, an examination of the descriptions revealed that whereas the rod-shaped organisms described by Jordan measured 1.0 by $2.5 \mu \mathrm{m}$ and had nonswelling sporangia, those described by Ford measured 0.5 by 2.5 to $4 \mu \mathrm{m}$ and produced swollen sporangia. Because the strain of Jordan has been lost, strain 26 of Ford, the only historical strain available, has been designated the type strain.

From the beginning, $B$. circulans has been a poorly defined species. Gibson and Topping ( $T$. Gibson and L. E. Topping, Soc. Agric. Bacteriol. Proc. Abstr., p. 43-44, 1938) referred to this species as a complex "exhibiting variation in several directions." Ensuing studies of the taxon by other researchers reinforced this view $(1$, $9,10,17,21,24)$. Such studies have disclosed a morphologically, nutritionally, physiologically, immunologically, and chemically heterogeneous group. Currently, the situation remains unchanged. In Bergey's Manual of Determinative Bacteriology, 8 th ed., the $B$. circulans group is considered to be an assemblage in which "variant features occur in many combinations without any obvious association in discrete groups" (5).
Very limited analyses of guanine-plus-cytosine $(G+C)$ contents have disclosed widely varying values for $B$. circulans strain (5). These limited observations suggest that genetic diversity exists among the strains identified as $B$. circulans, thus accounting for the heterogeneity of the species. Therefore, we undertook studies to assess the extent of $\mathrm{G}+\mathrm{C}$ variation among a large number of existing bacterial strains identified as $B$. circulans and to determine by deoxyribonucleic acid (DNA) reassociation experiments which of the strains, if any, were genetically related to the type strain. The fundamental characteristics of the species were established by examining the group of organisms determined to be related genetically to the type strain.

\section{MATERIALS AND METHODS}

Bacterial strains. The $B$. circulans strains used in this study are listed in Table 1 . The Northern Regional Research Laboratory (NRRL) designations include the prefixes B-, NRS-, and BD-. The prefix B-indicates the strains obtained directly from individuals or the strains isolated at the Northern Regional Research Center; the prefix NRS- designates strains from the Bacillus collection of N. R. Smith, which has been deposited in toto in the Agricultural Research Service Culture Collection (NRRL) by R. E. Gordon; and the prefix BD- designates the strains from the collection of B. Delaporte, a part of which has also been deposited in the Agricultural Research Service Culture Collection. In this paper all references to strains are to serial numbers (Table 1).

Characterization. Unless specified otherwise, the strains were characterized by the method of Gordon et 
TABLE 1. List of $B$. circulans strains used in this study

\begin{tabular}{|c|c|c|c|c|}
\hline $\begin{array}{c}\text { Serial } \\
\text { no. }\end{array}$ & Laboratory no. & Received as strain: & Source $^{a}$ & Strain history ${ }^{b}$ \\
\hline 1 & NRRL B-142 & PCI 221 & 1 & Streptomycin assay \\
\hline 2 & NRRL B-745 & $8 \cdot \mathrm{iv}$ & 2 & Deposited as "Vibrio perimastix" \\
\hline 3 & NRRL B-1359 & Q-19 & 3 & Circulin production \\
\hline 4 & NRRL B-1373 & 82 & 2 & Deposited as "Vibrio perimastix" \\
\hline 5 & NRRL B-1488 & & 2 & Deposited as "Vibrio perimastix" \\
\hline 6 & NRRL B-4031 & G3-7 & 4 & Isolated for phosphomannase activity \\
\hline 7 & NRRL B-4255 & 1 & 5 & $\begin{array}{l}\text { Isolated from honeybee broodcomb } \\
\text { in Finland }\end{array}$ \\
\hline 8 & NRRL NRS-290 & NRS-290 & 6 & $\begin{array}{l}\text { K. F. Kellerman, "Bacillus } \\
\text { amylolyticus" }\end{array}$ \\
\hline 9,10 & NRRL NRS-294, -295 & NRS-294, -295 & 6 & N. R. Smith, isolated from soil \\
\hline 11 & NRRL NRS-313 & NRS-313 & 6 & $\begin{array}{l}\text { ATCC } 4516 \text { from W. W. Ford } 7 \text { from } \\
\text { Kral collection, "Bacillus globigii" }\end{array}$ \\
\hline 12 & NRRL NRS-358 & NRS-358 & 6 & AMNH from W. W. Ford \\
\hline 13 & NRRL NRS-359 & NRS-359 & 6 & N. R. Smith \\
\hline 14 & NRRL NRS-375 & NRS-375 & 6 & N. R. Smith, isolated from soil \\
\hline $15-24$ & NRRL NRS-381 to -390 & NRS-381 to -390 & 6 & N. R. Smith, isolated from soil \\
\hline $25-28$ & NRRL NRS-396 to -399 & NRS-396 to -399 & 6 & N. R. Smith, isolated from soil \\
\hline 29-31 & NRRL NRS-625, -626, -639 & NRS-625, $-626,-639$ & 6 & $\begin{array}{l}\text { J. R. Porter from G. Bredemann, } \\
\text { "Bacillus nitidus" }\end{array}$ \\
\hline 32 & NRRL NRS-666 & NRS-666 & 6 & $\begin{array}{l}\text { University of Washington, "Bacillus } \\
\text { latus" }\end{array}$ \\
\hline $33-36$ & NRRL NRS-676 to -679 & NRS-676 to -679 & 6 & $\begin{array}{l}\text { N. R. Smith, migratory colonies } 1 \\
\text { through } 4 \text {, isolated from soil }\end{array}$ \\
\hline 37,38 & NRRL NRS-715, -716 & NRS-715, -716 & 6 & A. Russ-Munzer WI, WII \\
\hline 39 & NRRL NRS-726 & NRS-726 & 6 & $\begin{array}{l}\text { ATCC } 4513 \text { from W. W. Ford } 26 \text {, } \\
\text { type strain }\end{array}$ \\
\hline 40 & NRRL NRS-727 & NRS-727 & 6 & $\begin{array}{l}\text { ATCC } 61 \text { from AMC } 732 \text { ("Bacillus } \\
\text { fusiformis") from AMNH from } \\
\text { W. W. Ford } 10\end{array}$ \\
\hline 41 & NRRL NRS-728 & NRS-728 & 6 & $\begin{array}{l}\text { ATCC } 4515 \text { from W. W. Ford } 24, \\
\text { "B. fusiformis" }\end{array}$ \\
\hline 42 & NRRL NRS-729 & NRS-729 & 6 & $\begin{array}{l}\text { ATCC } 4516 \text { from W. W. Ford from } \\
\text { Kral collection, "Bacillus globigii", }\end{array}$ \\
\hline 43 & NRRL NRS-746 & NRS-746 & 6 & $\begin{array}{l}\text { ATCC } 4530 \text { from W. W. Ford } 28, \\
\text { "Bacillus terminalis", }\end{array}$ \\
\hline 44 & NRRL NRS-760 & NRS-760 & 6 & $\begin{array}{l}\text { S. F. Snieszko, "Bacillus } \\
\text { krzemieniewski," isolated from soil }\end{array}$ \\
\hline 45 & NRRL NRS-765 & NRS-765 & 6 & R. P. Myers, isolated from flour \\
\hline 46 & NRRL NRS-826 & NRS-826 & 6 & $\begin{array}{l}\text { J. R. Porter from G. Bredemann from } \\
\text { G. Stapp, "Bacillus carotarum" }\end{array}$ \\
\hline 47 & NRRL NRS-831 & NRS-831 & 6 & $\begin{array}{l}\text { J. R. Porter from NCTC } 2610 \text { from } \\
\text { W. W. Ford } 26\end{array}$ \\
\hline 48 & NRRL NRS-832 & NRS-832 & 6 & $\begin{array}{l}\text { J. R. Porter from H. G. Thornton, } \\
\text { "Bacillus cloisteroides"" }\end{array}$ \\
\hline 49 & NRRL NRS-838a & NRS-838a & 6 & $\begin{array}{l}\text { J. R. Porter from G. Bredemann, } \\
\text { "Bacillus cohaerens" }\end{array}$ \\
\hline 50 & NRRL NRS-839a & NRS-839a & 6 & $\begin{array}{l}\text { J. R. Porter from C. Stapp, " } B \text {. } \\
\text { cohaerens" }\end{array}$ \\
\hline 51 & NRRL NRS-841 & NRS-841 & 6 & $\begin{array}{l}\text { J. R. Porter from G. Bredemann, "B. } \\
\text { cohaerens" }\end{array}$ \\
\hline 52 & NRRL NRS-924 & NRS-924 & 6 & $\begin{array}{l}\text { J. R. Porter from M. Schieblich, } \\
\text { "Bacillus pabuli" }\end{array}$ \\
\hline 53 & NRRL NRS-977 & NRS-977 & 6 & $\begin{array}{l}\text { J. R. Porter from G. Bredemann, } \\
\text { "Bacillus supraresistans" }\end{array}$ \\
\hline 54 & NRRL NRS-1000 & NRS-1000 & 6 & $\begin{array}{l}\text { J. R. Porter from G. Bredemann, } \\
\text { "Bacillus validus" }\end{array}$ \\
\hline 55 & NRRL NRS-1029a & NRS-1029a & 6 & $\begin{array}{l}\text { J. Eisenberg, "Bacillus } \\
\text { schuylkilliensis" }\end{array}$ \\
\hline 56 & NRRL NRS-1061 & NRS-1061 & 6 & NCA \\
\hline 57 & NRRL NRS-1108 & NRS-1108 & 6 & $\begin{array}{l}\text { ATCC } 9500 \text { from W. H. Fuller, } \\
\text { "Bacillus aporrhoeus", }\end{array}$ \\
\hline
\end{tabular}


TABLE 1-Continued

\begin{tabular}{|c|c|c|c|c|}
\hline $\begin{array}{c}\text { Serial } \\
\text { no. }\end{array}$ & Laboratory no. & Received as strain: & Source $^{a}$ & Strain history ${ }^{b}$ \\
\hline 58 & NRRL NRS-1136 & NRS-1136 & 6 & ATCC 9966 from FDA strain PCI 221 \\
\hline 59 & NRRL NRS-1145 & NRS-1145 & 6 & A. L. Pollard, unknown strain \\
\hline $60-70$ & NRRL NRS-1167 to -1177 & NRS-1167 to -1177 & 6 & $\begin{array}{l}\text { H. W. Reuszer, Army 297B, 353, } \\
629,707,857,1292 \mathrm{C}, 1304,1324 \text {, } \\
1329,1335 \text {, and } 1376\end{array}$ \\
\hline 71 & NRRL NRS-1218 & NRS-1218 & 6 & C. McLeod \\
\hline 72 & NRRL NRS & & 6 & P. H. H. Gray, "Bacillus efflue \\
\hline 73 & NRRL NRS-1251 & NRS & 6 & P. H. H. Gray, "Bacillus kellermani" \\
\hline 74 & NRRL NRS-1254 & NRS & 6 & P. H. H. Gray, "Bacillus torquens" \\
\hline 75,76 & NRRL NRS-1275, -1278 & $5,-1278$ & 6 & M. Shaw $4204, \mathrm{~N}-3$ \\
\hline 77 & NRRL NRS-1280 & NRS-1280 & 6 & S. D. Henriksen \\
\hline 78,79 & NRRL NRS-1281, -1282 & , -1282 & 6 & $\begin{array}{l}\text { S. D. Henriksen from A. W. Turner } \\
\text { and C. E. Eales, strain A, strain B }\end{array}$ \\
\hline 80 & NRRL NRS-1337 & NRS & 6 & M. O’Brien \\
\hline $81-97$ & NRRL NRS-1340 to -1356 & NRS-1340 to -1356 & 6 & $\begin{array}{l}\text { F. E. Clark } 1,4,13,15,19,20,2,3 \text {, } \\
5,6,8,12,22,23,10,11 \text {, and } 14, \\
\text { isolated from soil }\end{array}$ \\
\hline $98-102$ & $\begin{array}{l}\text { NRRL NRS-1431, }-1433 \\
-1436\end{array}$ & $\begin{array}{l}\text { NRS-1431, }-1433 \text { to } \\
-1436\end{array}$ & 6 & $\begin{array}{l}\text { M. B. Allen, thermophilic strains } 15- \\
3,15-2,7-2,1 \text {, and } 2\end{array}$ \\
\hline 103-107 & NRRL BD-525 to -529 & 525 to 529 & 7 & Isolated from coarse Swedish sand \\
\hline & NRRL BD-530, 53 & 530,5 & 7 & from Canadian soil \\
\hline 110 & NRRL BD-532 & 532 & 7 & Isolated from Indian soil \\
\hline $111-116$ & NRRL BD-533 to -538 & 533 to 538 & 7 & Isolated from Canadian soil \\
\hline 117,118 & NRRL BD-539, - 540 & 539,540 & 7 & Isolated from Trinidadian soil \\
\hline 119 & NRRL BD-541 & 541 & 7 & Isolated from tadpole intestine \\
\hline $120-123$ & $\begin{array}{l}\text { NRRL BD-542, -543, -661, } \\
-662\end{array}$ & $542,543,661,662$ & 7 & Isolated from Canadian soil \\
\hline
\end{tabular}

${ }^{a}$ 1, Food and Drug Administration, Washington, D.C.; 2, P. H. H. Gray, McGill University, Montreal, Canada; 3, the Upjohn Co., Kalamazoo, Mich.; 4, M. C. Cadmus, Northern Regional Research Center, Peoria, Ill.; 5, depositor not known; 6, the N. R. Smith Bacillus collection maintained by R. E. Gordon, Rutgers University, New Brunswick, N.J.; 7, B. Delaporte, Laboratoire Cytologie Vegetale, Paris, France.

${ }^{b}$ FDA, Food and Drug Administration, Washington, D.C.; ATCC, American Type Culture Collection, Rockville, Md.; AMNH, American Museum of Natural History, New York, N.Y.; AMC, Walter Reed Army Medical Center, Washington, D.C.; NCTC, National Collection of Type Cultures, London, England; NCA, National Canners Association, San Francisco, Calif.

${ }^{c}$ Species names not on the Approved Lists of Bacterial Names (21) or validated since 1 January 1980 are in quotation marks.

al. (6). The carbohydrate fermentation tests were expanded to include the following as substrates: arabinose, cellobiose, fructose, galactose, glucose, lactose, maltose, mannitol, mannose, melibiose, rhamnose, ribose, salicin, sorbitol, sucrose, trehalose, and $x y$ lose. In addition to citrate, the utilization of acetate, fumarate, malate, and succinate was assessed. Hydrolysis of Tween 80 was determined by the method of Breuil and Gounot (2). The decomposition of arginine, lysine, and ornithine was determined in Moeller decarboxylase broth (16). The production of $\mathrm{H}_{2} \mathrm{~S}$ was detected by stab culturing in triple sugar iron agar (7). The method of Steel (22) was used for the oxidase test.

DNA isolation, $\mathrm{G}+\mathrm{C}$ ratios, and DNA reassociation. For DNA extraction, cells were grown for $24 \mathrm{~h}$ in tryptone glucose yeast extract broth $(8)$ at $28^{\circ} \mathrm{C}$ on a rotary shaker at $200 \mathrm{rpm}$. Sporulation was not observed in any of the cultures after $24 \mathrm{~h}$ of growth.

DNA was extracted and purified by a modification of the method of Marmur (14). The modification involved the use of hydroxyapatite (Bio-Gel HTP; BioRad Laboratories, Richmond, Calif.) chromatography (13) to produce highly purified DNA preparations. The purity and quality of each DNA preparation were determined by monitoring the ratio of absorbance at $260 \mathrm{~nm}$ to absorbance at $280 \mathrm{~nm}(1.8$ to 1.9$)$ and the ratio of absorbance at $260 \mathrm{~nm}$ to absorbance at $230 \mathrm{~nm}$ (2.0 to 2.3), using the method of Marmur (14), and by determining the melting curves, which include hyperchromicity values from 38 to $40 \%$ (12).

The $\mathrm{G}+\mathrm{C}$ content of the DNA was estimated by the buoyant density method (18). Buoyant density of DNA was measured by $\mathrm{CsCl}$ density gradient centrifugation in a Beckman model $\mathrm{E}$ ultracentrifuge. Micrococcus luteus (synonym, "Micrococcus lysodeikticus') DNA was purchased from the Sigma Chemical Co., St. Louis, Mo., and was used as an internal standard.

In preparation for renaturation studies, native double-stranded DNA was sheared by two passages through a French pressure cell at $10,000 \mathrm{lb} / \mathrm{in}^{2}$. After filtration through a membrane filter (pore size, 0.45 $\mu \mathrm{m}$; Millipore Corp., Bedford, Mass.), the sheared DNA solution was dialyzed exhaustively against a $0.001 \mathrm{M}$ ethylenediaminetetraacetate solution containing $5 \mathrm{ml}$ of $1 \times \mathrm{SSC}(0.15 \mathrm{M} \mathrm{NaCl}$ plus $0.015 \mathrm{M}$ trisodium citrate, $\mathrm{pH}$ 7.0) per liter. After dialysis, the 
DNA solution was dried by lyophilization. The dried material was dissolved in $2 \mathrm{ml}$ of double-distilled water.

The kinetics of DNA renaturation was measured in reaction mixtures that contained $0.25 \mathrm{ml}$ of $10 \times \mathrm{SSC}$, $0.2 \mathrm{ml}$ of dimethyl sulfoxide, approximately $70 \mu \mathrm{g}$ of DNA, and double-distilled water to bring the volume to $1 \mathrm{ml}$. In reaction mixtures containing two different DNAs, the quantities (about $35.0 \mu \mathrm{g}$ ) of the nucleic acids were adjusted to differ by no more than $0.15 \mu \mathrm{g}$. The reaction mixtures were placed in $0.4-\mathrm{ml}$ quartz cuvettes that were sealed with Teflon-lined stoppers. Denaturation and renaturation were effected and monitored with a Gilford UV-VIS thermal analyzer system. A denaturation temperature of $90^{\circ} \mathrm{C}$ was reached rapidly and was held for $10 \mathrm{~min}$ after the hyperchromic shift at $260 \mathrm{~nm}$. Subsequently, the temperature was lowered rapidly to $65^{\circ} \mathrm{C}$; the optical density at this point was taken to represent $0 \%$ renaturation (although some reassociation undoubtedly occurred). The absorbance change at $260 \mathrm{~nm}$ was monitored for $15 \mathrm{~min}$, during which the rate of renaturation was apparently linear even though second-order kinetics were displayed over a longer period of time. All determinations were repeated three times. Reassociation values (percentages) were calculated by using the equation of De Ley et al. (3).

\section{RESULTS}

Analyses of the DNAs of 123 strains identified as $B$. circulans revealed $\mathbf{G}+\mathbf{C}$ contents ranging from 37 to $60 \mathrm{mol \%}$ (Table 2). Of the strains examined, 18 clustered into a group having $\mathrm{G}+\mathrm{C}$ contents of 37 to 41 mol\%. The type strain (strain 39) belonged to this group. A major portion of the strains (93 strains) had G+C contents ranging from 46 to $55 \mathrm{~mol} \%$. In seven strains, the $\mathbf{G}+\mathrm{C}$ contents ranged from $\mathbf{4 2}$ to $\mathbf{4 5}$ mol\%. Another small group (five strains) had $\mathrm{G}+\mathrm{C}$ contents of 56 to $61 \mathrm{~mol} \%$.

DNA reassociation studies were done to determine the genetic relationship of the strains with $\mathbf{G}+\mathrm{C}$ contents ranging from 37 to $41 \mathrm{~mol} \%$ (Table 3). High relatedness values (90 to 100\%) were measured among the type strain and strains $11,12,40$ through 43,45 , and 47. Strain 57 showed moderate DNA relatedness (50 to $60 \%$ ) to these nine strains. These 10 strains were designated group I. Except for the moderate value of $60 \%$ when strains 19 and 21 were compared, the levels of DNA relatedness among the group II strains (strains 19, 21, 26, 46, 63, 82, and 94) were low (Table 3).

Table 4 shows a comparison of the phenotypic characteristics of group I and II strains. Our data indicated that group I consisted of a phenotypically homogeneous cluster of organisms. (Because of the homogeneity, the data for group I are not presented on a per strain basis.) Variability occurred only in the ability to grow in $7 \%$ $\mathrm{NaCl}$, Tween 80 hydrolysis, and the utilization of succinate. Strains 40, 45, and 57 failed to grow in $7 \% \mathrm{NaCl}$. Strain 57 also utilized succinate and
TABLE 2. Grouping of $B$. circulans strains according to $\mathrm{G}+\mathrm{C}$ content

\begin{tabular}{|c|c|c|}
\hline $\begin{array}{c}\mathrm{G}+\mathrm{C} \text { range } \\
(\mathrm{mol} \%)\end{array}$ & $\begin{array}{l}\text { No. of } \\
\text { strains }\end{array}$ & Laboratory no. \\
\hline $37.1-38$ & 3 & NRRL NRS-313, $-729,-831$ \\
\hline 38.1-39 & 10 & $\begin{array}{l}\text { NRRL NRS-358, -726, }-727 \\
-728,-746,-765,-826 \\
-1108,-1341,-1353\end{array}$ \\
\hline $39.1-40$ & 3 & $\begin{array}{l}\text { NRRL NRS-397, }-398 \text {, } \\
-1170\end{array}$ \\
\hline $40.1-41$ & 2 & NRRL NRS-385, -387 \\
\hline $41.1-42$ & 2 & NRRL BD-535, -661 \\
\hline $42.1-43$ & 2 & $\begin{array}{l}\text { NRRL NRS-1433; NRRL } \\
\text { BD-528 }\end{array}$ \\
\hline $43.1-44$ & 2 & NRRL BD-539, -543 \\
\hline $44.1-45$ & 1 & NRRL BD-530 \\
\hline $45.1-46$ & 5 & $\begin{array}{l}\text { NRRL NRS-1351, -1434, } \\
-1435 ; \text { NRRL BD-531, } \\
-540\end{array}$ \\
\hline $46.1-47$ & 6 & $\begin{array}{l}\text { NRRL B-745; NRRL } \\
\text { NRS-389, -396, -399, } \\
-1431,-1436\end{array}$ \\
\hline $47.1-48$ & 11 & $\begin{array}{l}\text { NRRL B-1373, -1488; } \\
\text { NRRL NRS-375, -677, } \\
\text {-1175, -1346, -1347, } \\
\text {-1350, -1352, -1356; } \\
\text { NRRL BD-525 }\end{array}$ \\
\hline $48.1-49$ & 14 & $\begin{array}{l}\text { NRRL B-1359; NRRL } \\
\text { NRS-1173,-1176, -1251, } \\
\text {-1280, -1344, -1345, -1349; } \\
\text { NRRL BD-526, -527, } \\
-529,-533,-537,-541\end{array}$ \\
\hline $49.1-50$ & 10 & $\begin{array}{l}\text { NRRL NRS-715, -716, -924, } \\
\text {-1061, -1174, -1177, -1348; } \\
\text { NRRL BD-533, -536, -538 }\end{array}$ \\
\hline $50.1-51$ & 15 & $\begin{array}{l}\text { NRRL B-142, -4031; NRRL } \\
\text { NRS-383, -386, -678, } \\
-679,-977,-1167,-1281 \\
-1337,-1342,-1343,-1354 ; \\
\text { NRRL BD-532, -662 }\end{array}$ \\
\hline $51.1-52$ & 10 & $\begin{array}{l}\text { NRRL NRS-295, }-381,-382, \\
-384,-666,-676,-1145, \\
-1168,1171,-1282\end{array}$ \\
\hline $52.1-53$ & 6 & $\begin{array}{l}\text { NRRL NRS-290, }-359,-832 \text {, } \\
\quad-1136,-1254,-1340\end{array}$ \\
\hline $53.1-54$ & 9 & $\begin{array}{l}\text { NRRL NRS-388, }-390,-625 \text {, } \\
-626,-839 \mathrm{a},-841,-1000, \\
.-1169,-1355\end{array}$ \\
\hline $54.1-55$ & 7 & $\begin{array}{l}\text { NRRL B-4255; NRRL } \\
\text { NRS-639, -838a, -1029a, } \\
-1218,-1275 ; \text { NRRL } \\
\text { BD-542 }\end{array}$ \\
\hline $55.1-56$ & 1 & NRRL NRS-1250 \\
\hline $57.1-58$ & 1 & NRRL NRS-1278 \\
\hline $58.1-59$ & 1 & NRRL NRS-1172 \\
\hline $59.1-60$ & 1 & NRRL NRS-294 \\
\hline $60.1-61$ & 1 & NRRL NRS-760 \\
\hline
\end{tabular}

was not able to hydrolyze Tween 80 . In contrast to group I strains, the group II strains exhibited variable reactions for the following characteristics: growth in lysozyme and $5 \% \mathrm{NaCl}$; acid production in litmus milk; nitrate reduction; 
TABLE 3. DNA relatedness among $B$. circulans strains with $\mathrm{G}+\mathrm{C}$ contents ranging from 37 to $41 \mathrm{~mol} \%$

\begin{tabular}{|c|c|c|c|c|c|c|c|c|c|c|c|c|c|c|c|c|}
\hline \multirow{2}{*}{ Strain } & \multicolumn{16}{|c|}{$\%$ Reassociation to DNAs from the following strains: ${ }^{a}$} \\
\hline & $12^{b}$ & 19 & 21 & 26 & $39^{c}$ & 40 & 41 & 42 & 43 & 45 & 46 & 47 & 57 & 63 & 82 & 94 \\
\hline $11^{b}$ & 100 & 6 & 10 & 9 & 100 & 95 & 100 & 98 & 97 & 100 & 36 & 90 & 58 & 11 & 35 & $\overline{6}$ \\
\hline 12 & & 5 & 27 & 18 & 98 & 99 & 100 & 100 & 100 & 97 & 29 & 85 & 51 & 12 & 33 & 10 \\
\hline 19 & & & 63 & 21 & 10 & 15 & 8 & 9 & 17 & 23 & 7 & 5 & 26 & 9 & 30 & 4 \\
\hline 21 & & & & 26 & 4 & 12 & 11 & 7 & 10 & 8 & 16 & 4 & 9 & 6 & 20 & 8 \\
\hline 26 & & & & & 24 & 14 & 25 & 10 & 25 & 18 & 16 & 6 & 21 & 10 & 8 & 14 \\
\hline $39^{c}$ & & & & & & 100 & 100 & 99 & 99 & 99 & 31 & 90 & 63 & 25 & 35 & 3 \\
\hline 40 & & & & & & & 98 & 100 & 100 & 98 & 36 & 87 & 56 & 28 & 32 & 5 \\
\hline 41 & & & & & & & & 97 & 96 & 100 & 27 & 86 & 67 & 31 & 30 & 11 \\
\hline 42 & & & & & & & & & 96 & 100 & 26 & 90 & 51 & 21 & 26 & 8 \\
\hline 43 & & & & & & & & & & 100 & 32 & 91 & 47 & 19 & 8 & 13 \\
\hline 45 & & & & & & & & & & & 32 & 88 & 48 & 18 & 10 & 10 \\
\hline 46 & & & & & & & & & & & & 26 & 35 & 20 & 19 & 14 \\
\hline 47 & & & & & & & & & & & & & 38 & 15 & 30 & 7 \\
\hline 57 & & & & & & & & & & & & & & 23 & 33 & 16 \\
\hline 63 & & & & & & & & & & & & & & & 23 & 33 \\
\hline 82 & & & & & & & & & & & & & & & & 10 \\
\hline
\end{tabular}

${ }^{a}$ Values are the averages of three determinations.

${ }^{b}$ Serial number (see Table 1).

${ }^{c}$ Type strain.

oxidase activity; Tween $\mathbf{8 0}$ hydrolysis; urease activity; utlization of acetate, citrate, fumarate, and succinate; and fermentation of arabinose, cellobiose, lactose, mannitol, melibiose, rhamnose, ribose, salicin, sorbitol, and xylose.

Morphologically, the cells of group I strains generally were 0.5 to 1 by 3 to $5 \mu \mathrm{m}$. Except for strain 94 , whose cells measured 1 to 2 by 5 to 10 $\mu \mathrm{m}$, the cells of group II strains had dimensions similar to those of the cells of group I strains. All group I strains were gram variable; group II included gram-variable and gram-positive strains. Except for strain 94, all group I and II strains produced swollen sporangia.

\section{DISCUSSION}

According to Table 2, only 18 of the 123 strains identified as $B$. circulans had $\mathrm{G}+\mathrm{C}$ contents in the range from 37 to $41 \mathrm{~mol} \%$, which included the $\mathrm{G}+\mathrm{C}$ content $(38.1 \mathrm{~mol} \%)$ of the type strain. It has been generally accepted that organisms with similar $\mathbf{G}+\mathrm{C}$ values may or may not be related. In the present study, high DNA relatedness values ( 90 to $100 \%$ ) showed that 9 of these 18 strains were closely related genetically. Since the nine strains included the type strain, these organisms must represent the species $B$. circulans as it was described by Ford (4). The extent of DNA relatedness (50 to 60\%) suggested that a tenth strain, strain 57 , was a subspecies. In general, the eight remaining strains were not related genetically.

Table 4 shows that the 10 genetically related strains (group I) displayed a minimum amount of phenotypic variation. Three strains failed to grow in $7 \% \mathrm{NaCl}$, and, in addition, one of these three did not hydrolyze Tween 80 but did utilize succinate. These three divergent characteristics were shown by strain 57 , an organism tentatively classified as a subspecies. Unfortunately, the small number of closely related strains was not suitable for obtaining a good estimate of the extent of phenotypic variability of the species. However, our data suggested that $B$. circulans could be characterized fundamentally as follows: gram-variable rod-shaped cells that measure 0.5 to 1 by 3 to $5 \mu \mathrm{m}$; are motile, produce swollen sporangia, grow anaerobically, are catalase positive, usually grow in $7 \% \mathrm{NaCl}$, do not reduce nitrate to nitrite, are oxidase negative, usually hydrolyze Tween 80 , hydrolize starch, do not utilize citrate, do not produce acetylmethylcarbinol, and ferment the common pentoses, hexoses, hexitols, and disaccharides. In contrast to group I strains, the seven genetically unrelated group II strains exhibited variable reactions for a wide range of characteristics (Table 4). Except for its resistance to lysozyme and its failure to hydrolyze casein, strain 94 generally showed the characteristics of Bacillus megaterium. On the basis of their characteristics, however, the other group II strains could not be readily associated with any of the other firmly established Bacillus species. These unidentified strains are being studied to determine their taxonomic positions.

In 106 of the 123 strains, the $\mathrm{G}+\mathrm{C}$ contents ranged from 45 to $60 \mathrm{~mol} \%$. Sueoka (23) suggested that the probability that DNA molecules have identical nucleotide sequences of gene length is low when the differences in $\mathrm{G}+\mathrm{C}$ values 
TABLE 4. Characteristics of $B$. circulans with $\mathrm{G}+\mathrm{C}$ contents ranging from 37 to $41 \mathrm{~mol} \%^{a}$

\begin{tabular}{|c|c|c|c|c|c|c|c|c|}
\hline \multirow{2}{*}{ Characteristics $^{b}$} & \multirow{2}{*}{$\underset{I^{c}}{\text { Group }}$} & \multicolumn{7}{|c|}{ Strain (serial no.) } \\
\hline & & 19 & 21 & 26 & 46 & 63 & 82 & 94 \\
\hline \multicolumn{9}{|l|}{ Morphology } \\
\hline Width $(\mu \mathrm{m})$ & $0.5-1$ & $0.5-1$ & $0.5-1$ & $0.5-1$ & $0.5-1$ & $0.5-1$ & $0.5-1$ & $1-2$ \\
\hline Length $(\mu \mathrm{m})$ & $3-7$ & $3-5$ & $3-5$ & $3-5$ & $3-5$ & $3-5$ & $4-8$ & $5-10$ \\
\hline Gram stain & $\mathrm{v}$ & $\mathrm{v}$ & v & + & $\mathrm{v}$ & + & $\mathrm{v}$ & + \\
\hline Swollen sporangium & + & + & + & + & + & + & + & - \\
\hline Anaerobic growth & + & + & + & + & + & + & + & - \\
\hline Growth in lysozyme & - & - & - & + & - & - & - & + \\
\hline \multicolumn{9}{|l|}{ Growth in: } \\
\hline $5 \% \mathrm{NaCl}$ & + & - & - & + & + & - & - & + \\
\hline $7 \% \mathrm{NaCl}$ & + & - & - & - & - & - & - & - \\
\hline Amino acid-decomposing enzyme: argine dihydrolase & - & - & - & - & - & - & - & + \\
\hline Litmus milk & A & nc & nc & A & A & nc & A & A \\
\hline Nitrate reduction to nitrite & - & + & + & + & + & - & - & + \\
\hline Oxidase & - & + & + & + & - & + & + & + \\
\hline Tween 80 hydrolysis & + & - & + & + & - & + & - & - \\
\hline Urease & - & - & - & - & - & + & - & + \\
\hline $\mathrm{pH}$ in VP broth & 4.9 & 5.0 & 5.0 & 4.9 & 4.9 & 4.9 & 5.0 & 4.9 \\
\hline \multicolumn{9}{|l|}{ Utilization of: } \\
\hline Acetate & + & + & + & + & - & + & + & + \\
\hline Citrate & - & - & + & - & - & - & - & + \\
\hline Fumarate & + & + & + & - & - & + & - & + \\
\hline Malate & + & + & + & - & + & + & - & + \\
\hline Succinate & - & - & + & - & - & + & - & + \\
\hline \multicolumn{9}{|l|}{ Acid from: } \\
\hline Arabinose & + & - & - & + & + & + & + & - \\
\hline Cellobiose & + & - & - & + & + & + & + & + \\
\hline Lactose & + & + & - & + & + & + & + & - \\
\hline Mannitol & + & - & + & + & + & + & + & - \\
\hline Melibiose & + & + & - & + & + & + & + & - \\
\hline Rhamnose & + & + & - & + & + & - & + & - \\
\hline Ribose & + & + & + & + & + & - & + & + \\
\hline Salicin & + & + & + & + & + & - & + & - \\
\hline Sorbitol & + & - & - & - & + & + & + & - \\
\hline Xylose & + & - & - & + & + & + & + & - \\
\hline
\end{tabular}

${ }^{a}$ Symbols: + , positive; -, negative; $\mathrm{v}$, variable; $\mathrm{A}$, acid produced; nc, no change.

${ }^{b}$ All strains were motile; grew at $\mathrm{pH}$ 5.7; produced catalase; hydrolyzed starch; and produced acid from fructose, galactose, glucose, maltose, mannose, sucrose, and trehalose. No strain grew in $10 \% \mathrm{NaCl}$; produced lysine decarboxylase, ornithine decarboxylase, egg yolk lecithinase, $\mathrm{H}_{2} \mathrm{~S}$, or indole; hydrolyzed casein; or gave a positive Voges-Proskauer (VP) test reaction.

${ }^{c}$ Type strain included in this group.

exceed $10 \mathrm{~mol} \%$. Furthermore, accumulated data have indicated that within a genus, strains with $\mathrm{G}+\mathrm{C}$ contents varying by $2 \mathrm{~mol} \%$ or more usually are members of separate species $(15,19)$. Therefore, the significant differences in $\mathrm{G}+\mathrm{C}$ content among many of the organisms which we studied indicated that this group of 106 strains consisted of members of several different species. Perhaps some of these will prove to be related, because a number of the strains may share a common spore antigen (24) and have similar $\mathbf{G}+\mathrm{C}$ contents (Table 2). Whether these 
strains are strains of new species or existing species will be determined in continuing studies.

DNA relatedness studies and $\mathrm{G}+\mathrm{C}$ analyses showed that the majority of strains which we examined were erroneously classified as $B$. circulans. Consequently, the phenotypic heterogeneity of this species is not due to inherent variability of genetically related strains, but is due to inclusion of genetically unrelated organisms.

\section{ACKNOWLEDGMENT}

We thank Judith Scheppler for her able technical assistance.

\section{LTTERATURE CITED}

1. Bradley, D. E., and J. G. Franklin. 1958. Electron microscope survey of the surface configuration of spores of the genus Bacillus. J. Bacteriol. 76:618-630.

2. Breuil, C., and A. M. Gounot. 1972. Recherches preliminaires sur les bacteries lipolytiques psychrophiles des sols et des eaux. Can. J. Microbiol. 18:1445-1451.

3. De Ley, J., H. Cattoir, and A. Reynaerts. 1970. The quantitative measurement of DNA hybridization from renaturation rates. Eur. J. Biochem. 12:133-142.

4. Ford, W. W. 1916. Studies on aerobic spore-bearing nonpathogenic bacteria. II. Miscellaneous cultures. J. Bacteriol. 1:518-526.

5. Gibson, T., and R. E. Gordon. 1974. Genus I. Bacillus Cohn 1872, p. 529-550. In R. E. Buchanan and N. E. Gibbons (ed.), Bergey's manual of determinative bacteriology, 8th ed. The Williams \& Wilkins Co., Baltimore.

6. Gordon, R. E., W. C. Haynes, and C. H. Pang. 1973. The genus Bacillus. Agricultural handbook no. 427. U.S. Department of Agriculture, Washington, D.C.

7. Hajna, A. A. 1945. Triple-sugar iron agar medium for the identification of the intestinal group of bacteria. J. Bacteriol. 49:516-517.

8. Haynes, W. C., L. J. Wickerham, and C. W. Hesseltine. 1955. Maintenance of cultures of industrially important microorganisms. Appl. Microbiol. 3:361-368.

9. Hill, I. R., and T. R. G. Gray. 1967. Application of the fluorescent-antibody technique to an ecological study of bacteria in soil. J. Bacteriol. 93:1888-1896.

10. Jayne-Williams, D. J., and G. C. Cheeseman. 1960. The differentiation of bacterial species by paper chromatography. IX. The genus Bacillus: a preliminary investigation. J. Appl. Bacteriol. 23:250-268.

11. Jordan, E. O. 1890 . A report on certain species of bacteria observed in sewage, p. 821-844. In Sedgewick, A report of the biological work of the Lawrence Experiment Station, including an account of methods employed and results obtained in the microscopical and bacteriological investigation of sewage and water. Report on water supply and sewerage, part 2. Massachusetts State Board of Health, Boston.

12. Mandel, M., and J. Marmur. 1968. Use of ultraviolet absorbance-temperature profile for determining the guanine plus cytosine of DNA. Methods Enzymol. 12B:195206.

13. Markov, G. G., and I. G. Ivanov. 1974. Hydroxyapatite column chromatography procedure for isolation of purified DNA. Anal. Biochem. 59:559-563.

14. Marmur, J. 1961. A procedure for the isolation of deoxyribonucleic acid from microorganisms. J. Mol. Biol. 3:208-218.

15. Marmur, J., S. Falkow, and M. Mandel. 1963. New approaches to bacterial taxonomy. Annu. Rev. Microbiol. 17:329-372.

16. Moeller, V. 1955. Simplified tests for some amino acid decarboxylases and for the arginine dihydrolase system. Acta Pathol. Microbiol. Scand. 36:158-172.

17. Proom, H., and B. C. J. G. Knight. 1955. The minimal nutritional requirements of some species of the genus Bacillus. J. Gen. Microbiol. 13:474-480.

18. Schildkraut, C. L., J. Marmur, and P. Doty. 1962. Determination of the base composition of deoxyribonucleic acid from its buoyant density in $\mathrm{CsCl}$. J. Mol. Biol. 4:430 443.

19. Seidler, R. J., M. D. Knittel, and C. Brown. 1975. Potential pathogens in the environment: cultural reactions and nucleic acid studies on Klebsiella pneumoniae from clinical and environmental sources. Appl. Microbiol. 29:819825.

20. Skerman, V. B. D., V. McGowan, and P. H. A. Sneath (ed.). 1980. Approved lists of bacterial names. Int. J. Syst. Bacteriol. 30:225-420.

21. Smith, N. R., R. E. Gordon, and F. E. Clark. 1952. Aerobic sporeforming bacteria. Agriculture monograph no. 16. U.S. Department of Agriculture, Washington, D.C.

22. Steel, K. J. 1961. The oxidase reaction as a taxonomic tool. J. Gen. Microbiol. 25:297-306.

23. Sueoka, N. 1961. Variation and heterogeneity of base composition of deoxyribonucleic acids: a compilation of new and old data. J. Mol. Biol. 3:31-40.

24. Wolf, J., and M. S. U. Chowdhury. 1971. The Bacillus circulans complex: biochemical and immunological studies, p. 227-245. In A. N. Barker, G. W. Gould, and J. Wolf (ed.), Spore research 1971. Academic Press, Inc., New York. 